\title{
Potential effects of a flavonoid, hesperidin on SARS-CoV-2 disease
}

\section{To the Editor}

The novel coronavirus, COVID-19 or severe acute respiratory syndrome coronavirus 2 (SARSCoV-2) was first identified in China in December 2019 [1].

SARS-CoV-2 uses the receptor angiotensin-converting enzyme 2 (ACE2) for infection by the transmembrane protease, serine 2 (TMPRSS2) on the surface of the host cell entry [2]. SARSCoV-2 is not only rapidly spreading but has become a global pandemic that may challenge the economic, medical and public health of the world [3]. Following infection by SARS-CoV-2, cytokine storm is mediated by the release of large amounts of IFN- $\alpha$, IL-1b, IL-6, IL-12, IL-18, IL-33, TNF- $\alpha$, TGF $\beta$, etc. by immune effector cells [4, 5]. Various biological compounds such as of flavonoids, have been showed as anti-asthmatic [6, 7], therapeutic, antioxidant, antiviral and with other properties in nature $[8,9]$. Anti-SARS coronavirus 3C-like protease effects of plant-derived phenolic compounds were also reported [10]. Hesperidin is a common flavone glycoside found in citrus fruit such as lemons [11]. The virions load in hesperidin-treated Madin-Darby canine kidney (MDCK) cells were 148-fold less than that of the untreated MDCK cells infected by influenza virus. Hesperidin $(100 \mu \mathrm{M})$ also decreased viral RNA level and enhanced antiviral state-associated genes expression in the uninfected A549 cells [12].

The inhibitory effect of hesperidin $(0-25 \mathrm{mM})$ on influenza A virus (IAV) infected MDCK cells induced distinct reduction in IAV replication. Hesperidin had no cytotoxic effects on MDCK cells [13]. It is the compound that could target the binding interface between SARS-CoV-2 Spike and
ACE2 human receptors [14]. It has been reported that hesperidin strongly binds to the active site of RNA dependent RNA polymerase (RdRp), which catalyzes SARS-CoV-2 RNA replication [15].

Hesperidin $(2.0 \mathrm{mg} / \mathrm{mL})$ significantly reduced expression of pro-inflammatory cytokines in human osteoarthritis (OA) chondrocytes [16].

The effects of hesperidin $(5,10,50$ and $100 \mu \mathrm{M})$ on hydrogen peroxide $\left(\mathrm{H}_{2} \mathrm{O}_{2}\right)$ induced oxidative stress damages to chondrocytes, downregulated the mRNA levels of COX-2, IL- $1 \beta$, TNF- $\alpha$, MMP-3, MMP-9, and upregulated IL-10, TIMP-1, SOX9 [17]. Treatment of Aeromonas hydrophila-infected mice with hesperidin $(250 \mathrm{mg} / \mathrm{kg}$ b.wt.), significantly suppressed inflammatory response through reduction of reactive oxygen species (ROS) production and adhesion molecules expression, as well as an increase of $\mathrm{CD} 4+/$ CD8 + cell ratio [18]. Hesperidin $(100 \mathrm{mg} / \mathrm{kg}$. b.w) also reduced lipid peroxidation and inflammatory mediators (IL- $1 \beta$ and TNF- $\alpha$ ), while increased anti-inflammatory cytokines (IL-4 and IL-10) in induced Parkinson's disease in male C57BL/6 mice [19].

Nitric oxide (NO) has the potential therapeutic effects on acute respiratory distress syndrome in patients with COVID-19, and inhaled nitric oxide may become an alternate rescue therapy in patients with COVID-19 [20]. NO may inhibit the early stage in viral replication and could prevent viral spread, and recovery of patients [21]. Treatment of bovine aortic endothelial cells (BAEC) with hesperedin $(10 \mu \mathrm{M}$ for $5 \mathrm{~h})$ stimulated production of NO [22]. The effect of hesperidin (15 and $30 \mathrm{mg} / \mathrm{kg}$ ) on cardiovascular remodeling in rats significantly reduced oxidative stress markers, TNF- $\alpha$, TGF- $\beta 1$, and enhanced plasma

Address for correspondence: Mohammad Reza Khazdair , Pharmaceutical Science and Clinical Physiology, Cardiovascular Diseases Research Center, Birjand University of Medical Sciences, Birjand, Iran; e- mail: khazdairMR@Bums.ac.ir

DOI: 10.5603/ARM.a2021.0093 | Received: 14.01.2021 | Copyright (C) 2021 PTChP | ISSN 2451-4934 | e-ISSN $2543-6031$

This article is available in open access under Creative Common Attribution-Non-Commercial-No Derivatives 4.0 International (CC BY-NC-ND 4.0) license, allowing to download articles and share them with others as long as they credit the authors and the publisher, but without permission to change them in any way or use them commercially. 
nitric oxide metabolite (NOx) in L-NAME-induced hypertension in rats [23]. The results of a review of different studies in China showed that less than $10 \%$ of smokers infected with COVID-19 [24]. The intermittent bursts of high NO concentration in cigarette smoke may be a protective mechanism against SARS-CoV-2 [25].

Hesperidin may be used as a promising drug candidate for the prevention and treatment of SARS-CoV-2 due to antiviral, anti-inflammatory and antioxidant properties. Furthermore, hesperidin interferes with viral entry through ACE2 receptors, release of NO into the blood stream and improved immune system.

\section{Conflict of interest}

The author declares no conflicts of interest.

\section{References:}

1. Guan WJ, Ni ZY, Hu Yu, et al. China Medical Treatment Expert Group for Covid-19. Clinical characteristics of coronavirus disease 2019 in China. N Engl J Med. 2020; 382(18): 1708-1720, doi: 10.1056/NEJMoa2002032, indexed in Pubmed: 32109013.

2. Hoffmann M, Kleine-Weber H, Schroeder S, et al. SARS-CoV-2 cell entry depends on ACE2 and TMPRSS2 and is blocked by a clinically proven protease inhibitor. Cell. 2020; 181(2): 271280.e8, doi: 10.1016/j.cell.2020.02.052, indexed in Pubmed: 32142651.

3. Singhal T. A review of coronavirus disease-2019 (COVID-19). India J Pediatric. 2020; 87(4): 281-286, doi: 10.1007/s12098020-03263-6, indexed in Pubmed: 32166607.

4. Cameron MJ, Bermejo-Martin JF, Danesh A, et al. Human immunopathogenesis of severe acute respiratory syndrome (SARS). Virus Res. 2008; 133(1): 13-19, doi: 10.1016/j.virusres.2007.02.014, indexed in Pubmed: 17374415.

5. Zhang H, Du F, Cao XJ, et al. Evidence-Based Medicine Chapter of China International Exchange and Promotive Association for Medical and Health Care (CPAM), Chinese Research Hospital Association (CRHA). Clinical features of patients infected with 2019 novel coronavirus in Wuhan, China. Lancet. 2020; 395(10223): 497-506, doi: 10.1016/S0140-6736(20)30183-5, indexed in Pubmed: 31986264.

6. Khazdair MR, Anaeigoudari A, Kianmehr M. Anti-Asthmatic effects of and its constituents, a review. J Pharmacopuncture. 2019; 22(3): 122-130, doi: 10.3831/KPI.2019.22.016, indexed in Pubmed: 31673441.

7. Kianmehr M, Khazdair MR. Possible therapeutic effects of stigma and its petal flavonoid, kaempferol, on respiratory disorders. Pharm Biol. 2020; 58(1): 1140-1149, doi: 10.1080/13880209.2020.1844762, indexed in Pubmed: 33295229.

8. Tapas AR, Sakarkar DM, Kakde RB. Flavonoids as nutraceuticals: A review. Tropical Journal of Pharmaceutical Research. 2008; 7(3), doi: 10.4314/tjpr.v7i3.14693.

9. Khazdair MR, Alavinezhad A, Boskabady MH. Carvacrol ameliorates haematological parameters, oxidant/antioxidant biomarkers and pulmonary function tests in patients with sulphur mustard-induced lung disorders: A randomized double-blind clinical trial. J Clin Pharm Ther. 2018; 43(5): 664-674, doi: 10.1111/jcpt.12684, indexed in Pubmed: 29574804.

10. Lin CW, Tsai FJ, Tsai CH, et al. Anti-SARS coronavirus 3C-like protease effects of Isatis indigotica root and plant-derived phenolic compounds. Antiviral Res. 2005; 68(1): 36-42, doi: 10.1016/j.antiviral.2005.07.002, indexed in Pubmed: 16115693.

11. Wilmsen PK, Spada DS, Salvador M. Antioxidant activity of the flavonoid hesperidin in chemical and biological systems. J Agric Food Chem. 2005; 53(12): 4757-4761, doi: 10.1021/ jf0502000, indexed in Pubmed: 15941311.

12. Dong W, Wei X, Zhang F, et al. A dual character of flavonoids in influenza A virus replication and spread through modulating cell-autonomous immunity by MAPK signaling pathways. Sci Rep. 2014; 4: 7237, doi: 10.1038/srep07237, indexed in Pubmed: 25429875.

13. Saha RK, Takahashi T, Suzuki T. Glucosyl hesperidin prevents influenza a virus replication in vitro by inhibition of viral sialidase. Biol Pharm Bull. 2009; 32(7): 1188-1192, doi: 10.1248/ bpb.32.1188, indexed in Pubmed: 19571383.

14. Wu C, Liu Y, Yang Y, et al. Analysis of therapeutic targets for SARS-CoV-2 and discovery of potential drugs by computational methods. Acta Pharm Sin B. 2020; 10(5): 766-788, doi: 10.1016/j.apsb.2020.02.008, indexed in Pubmed: 32292689.

15. Singh S, Sk MdF, Sonawane A, et al. Plant-derived natural polyphenols as potential antiviral drugs against SARS-CoV-2 RNA-dependent RNA polymerase (RdRp) inhibition: an analysis. J Biomol Struct Dyn. 2020 [Epub ahead of print]: 1-16, doi: 10.1080/07391102.2020.1796810, indexed in Pubmed: 32720577.

16. Fu Z, Chen Z, Xie Q, et al. Hesperidin protects against IL$1 \beta$-induced inflammation in human osteoarthritis chondrocytes. Exp Ther Med. 2018; 16(4): 3721-3727, doi: 10.3892/ etm.2018.6616, indexed in Pubmed: 30233731.

17. Tsai YF, Chen YR, Chen JP, et al. Effect of hesperidin on anti-inflammation and cellular antioxidant capacity in hydrogen peroxide-stimulated human articular chondrocytes. Process Biochemistry. 2019; 85: 175-184, doi: 10.1016/j.procbio.2019.07.014.

18. Abuelsaad ASA, Allam G, Al-Solumani AAA. Hesperidin inhibits inflammatory response induced by Aeromonas hydrophila infection and alters CD4+/CD8+ T cell ratio. Mediators Inflamm. 2014; 2014: 393217, doi: 10.1155/2014/393217, indexed in Pubmed: 24891765.

19. Manivasagam T, Nataraj J, Tamilselvam K, et al. Antioxidant and anti-inflammatory potential of hesperidin against 1-methyl-4-phenyl-1, 2, 3, 6-tetrahydropyridine-induced experimental Parkinson's disease in mice. International Journal of $\mathrm{Nu}$ trition, Pharmacology, Neurological Diseases. 2013; 3(3): 294, doi: 10.4103/2231-0738.114875.

20. Kobayashi J, Murata I. Nitric oxide inhalation as an interventional rescue therapy for COVID-19-induced acute respiratory distress syndrome. Ann Intensive Care. 2020; 10(1): 61, doi: 10.1186/s13613-020-00681-9, indexed in Pubmed: 32436029.

21. Hedenstierna G, Chen L, Hedenstierna M, et al. Nitric oxide dosed in short bursts at high concentrations may protect against Covid 19. Nitric Oxide. 2020; 103: 1-3, doi: 10.1016/j. niox.2020.06.005, indexed in Pubmed: 32590117.

22. Rizza S, Muniyappa R, Iantorno M, et al. Citrus polyphenol hesperidin stimulates production of nitric oxide in endothelial cells while improving endothelial function and reducing inflammatory markers in patients with metabolic syndrome. J Clin Endocrinol Metab. 2011; 96(5): E782-E792, doi: 10.1210/ jc.2010-2879, indexed in Pubmed: 21346065.

23. Maneesai P, Bunbupha S, Potue P, et al. Hesperidin prevents nitric oxide deficiency-induced cardiovascular remodeling in rats via suppressing TGF- 1 and MMPs protein expression. Nutrients. 2018; 10(10), doi: 10.3390/nu10101549, indexed in Pubmed: 30347737.

24. Berlin I, Thomas D, Le Faou AL, et al. COVID-19 and smoking. Nicotine Tob Res. 2020; 22(9): 1650-1652, doi: 10.1093/ntr/ ntaa059, indexed in Pubmed: 32242236.

25. Froldi G, Dorigo P. Endothelial dysfunction in Coronavirus disease 2019 (COVID-19): Gender and age influences. Med Hypotheses. 2020; 144: 110015, doi: 10.1016/j.mehy.2020.110015, indexed in Pubmed: 32592919. 